\title{
PRELIMINARY STUDY ON THE EFFECT OF VITAMIN C ON THE GROWTH AND SURVIVAL RATE OF THE FRESHWATER PRAWN (Macrobrachium rosenbergii) LARVAE
}

\author{
Ikhsan Khasani*)
}

\begin{abstract}
This experiment was conducted to investigate the influence of vitamin $\mathrm{C}$ on growth and survival rate of freshwater prawn larvae. The treatment dosages of vitamin $C$ were 0.0 , and $0.75 \mathrm{mg} / \mathrm{L}$. Each treatment was in triplicates and arranged in a complete randomized design. Vitamin $\mathrm{C}$ was given to the larval rearing media every three days. Larvae were cultured in six conical fibreglass tanks of $50 \mathrm{~L}$ volume installed in a fibreglass tank $\left(2 \times 0.8 \times 0.8 \mathrm{~m}^{3}\right)$ filled with water for temperature stabilizer. Each conical tank was stocked with 6,500 larvae (nauplii). Artemia nauplii were given on D3 and egg custard as artificial feed on D9. Larval rearing was done for 25 days in constant temperature $\left(29^{\circ} \mathrm{C}-31^{\circ} \mathrm{C}\right)$ using automatic heater. Statistical analysis showed that metamorphosis speed of larvae was significantly affected by adding of vitamin C $(P<0.05)$, but survival rate was similar $(P>0.05)$. Addition of vitamin $C$ also resulted in a better growth of freshwater prawn larvae.
\end{abstract}

\section{KEYWORDS: vitamin C, grow, freshwater prawn, survival rate}

\section{INTRODUCTION}

Giant freshwater prawn (Macrobrachium rosenbergii de Man) is a potential aquaculture commodity in Indonesia. Recently, this commodity has been being developed in both extensive and intensive level. Increasing of seed demand is its direct consequence. Unfortunately, there are still some problems in culture of the freshwater prawn, i.e. the quality and supply of seeds.

The growth of freshwater prawn larvae are influenced by some environmental factors including temperature, rearing media, nutrients, light intensity and water quality (Aquacop, 1983; Hadie \& Hadie, 1993; New \& Valenti, 2002). Moulting is a routine process for prawn to growth at both young and adult stages. During metamorphosis process to the postlarvae stage, larvae moult eleven times (Uno \& Soo, 1969; D'Abramo, 2002). At this condition prawn larvae are weak due to decreasing feed con- sumption and having soft shell. At this condition, high mortality often occurs if water quality is inferior. The mortality of larvae was also caused by its cannibalism where health larvae will feed on the moulting larvae. This low survival rate of Macrobrachium rosenbergii in larval stage often inhibits the development of full economic potential of this crustacean.

One method to increase the fish immunity is by vitamin C supplemention to its feed. Masumoto et al. (1991) stated that vitamin C is essential component for fish immunity. Bad quality of water and physiological change of fish body disturb the fish, so optimal availability of vitamin C in fish body is very essential to prevent stress and increase disease resistances. Enrichment of vitamin C (as ascorbil palmitate) in live food of $M$. rosenbergii larvae was done by Merchie et al. (1993) with result that various enrichment levels of vitamin $C$ had no differences on growth nor survival, but gave

\footnotetext{
") Research Institute for Freshwater Fish Breeding and Aquaculture, Sukamandi, Indonesia
} 
a significantly positive effect on the physiological condition of the postlarvae.

Based on those studies, we tried to use vitamin C (as ascorbic acid) on freshwater prawn larvae rearing through culture media to find the effectivity of this method and the effect of vitamin C on growth and survival rate of giant freshwater prawn larvae.

\section{MATERIALS AND METHODS}

One-day-old (D1) giant freshwater prawn larvae were used in this study. The dosages of vitamin C were 0.00 and $0.75 \mathrm{mg} / \mathrm{L}$. Each treatment was applied in triplicates and arranged in a completely randomized design. Vitamin $C$ was given to the media for larval rearing every three days. Larvae were reared in clear water system with the salinity of the media of 12 ppt (Aquacop, 1983; D'Abramo, 2002). Larvae were maintained in six conical fiberglass tanks of $50 \mathrm{~L}$ volume installed in a $2 \mathrm{x}$ $0.8 \times 0.8 \mathrm{~m}^{3}$ fiber tank filled with water for temperature buffer. Each conical tank was stocked with 6,500 larvae (nauplii).

Artemia nauplii were given to the three day old (D3) larvae following egg custard as the artificial feed starting on D9 larvae. Larval rearing was done for 25 days in a constant temperature of $29-31{ }^{\circ} \mathrm{C}$ regulated by an automatic heater. The water quality was maintained in a good condition by siphonization and water exchange of about 60 percent after the larvae were given artificial feed starting on D9 every day.

The growth stage of larvae (Larval Stage Index, LSI) was observed every three days by sampling 25 individuals per tank. Water quality variable were measured every week. The data of survival and total post larvae were analyzed by Anova followed by LSD test.

\section{RESULTS}

Significantly higher total number of postlarvae was observed in larval rearing with vitamin C supplementation (Fig 1). The larvae Stage Index (LSI) showed that addition vitamin $C$ is effective to support larval growth (Table 1).

However, vitamin C supplementation into larval rearing media did not result in significantly higher survival rate of larvae on D25 (Fig 2).

Water quality variables showed that ammonia and nitrite value were significantly increased up to of $0.52 \mathrm{mg} / \mathrm{L}$ and $0.46 \mathrm{mg} / \mathrm{L}$, respectively, after giving artificial feed (egg custard), but the other variables were suitable for larval rearing.

\section{DISCUSSION}

Total of postlarvae number on D25 was significantly higher $(P<0.05)$ between treatments. This data showed that vitamin $\mathrm{C}$ gave positive effect for larvae to recovery after moulting and increased larval resistance to diseases and stress. The LSI value of the vitamin C treatments was higher than that of control. Masumoto et al. (1991) stated that vitamin C was the essential component for fish immunity, optimal availability of vitamin C in fish body is very essential to increase stress and disease resistance.

Main target of freshwater prawn hatchery is the juvenile (pasca larvae stage) production. Although survival rate of larvae at 25-day was not significant $(P>0.05)$ but total production of pasca larvae were predicted will significant. Number of larvae stage 9 (nine) and 10 (ten) at treatment of $0 \mathrm{mg} / \mathrm{L}$ vitamint $\mathrm{C}$ at 24 -day is 1650 larvae higher than treatment of $0.75 \mathrm{mg} /$ L (315 larvae). According to that data, predic-

Tabel 1. Average of LSI of giant fresh water prawn larvae during the trial

\begin{tabular}{cccccccccc}
\hline & \multicolumn{10}{c}{ LSI } \\
\cline { 2 - 10 } $\begin{array}{c}\text { Treat ment } \\
\text { (vit amin C) }\end{array}$ & \multicolumn{10}{c}{ Days } \\
\cline { 2 - 10 } & $\mathbf{0}$ & $\mathbf{3}$ & $\mathbf{6}$ & $\mathbf{9}$ & $\mathbf{1 2}$ & $\mathbf{1 5}$ & $\mathbf{1 8}$ & $\mathbf{2 1}$ & \multicolumn{1}{c}{$\mathbf{2 4}$} \\
\hline $0.00 \mathrm{mg} / \mathrm{L}$ & 1 & 2.04 & 3.54 & 5.04 & 6.35 & 7.43 & 8.95 & 9.66 & 10,$29 ;$ \\
& & & & & & & & & $\mathrm{PL}$ \\
$0.75 \mathrm{mg} / \mathrm{L}$ & 1 & 2.89 & 4.09 & 5.96 & 7.09 & 8.55 & 9,$68 ;$ & 10,$54 ;$ & 10,$80 ;$ \\
& & & & & & & $\mathrm{PL}$ & $\mathrm{PL}$ & $\mathrm{PL}$ \\
\hline
\end{tabular}




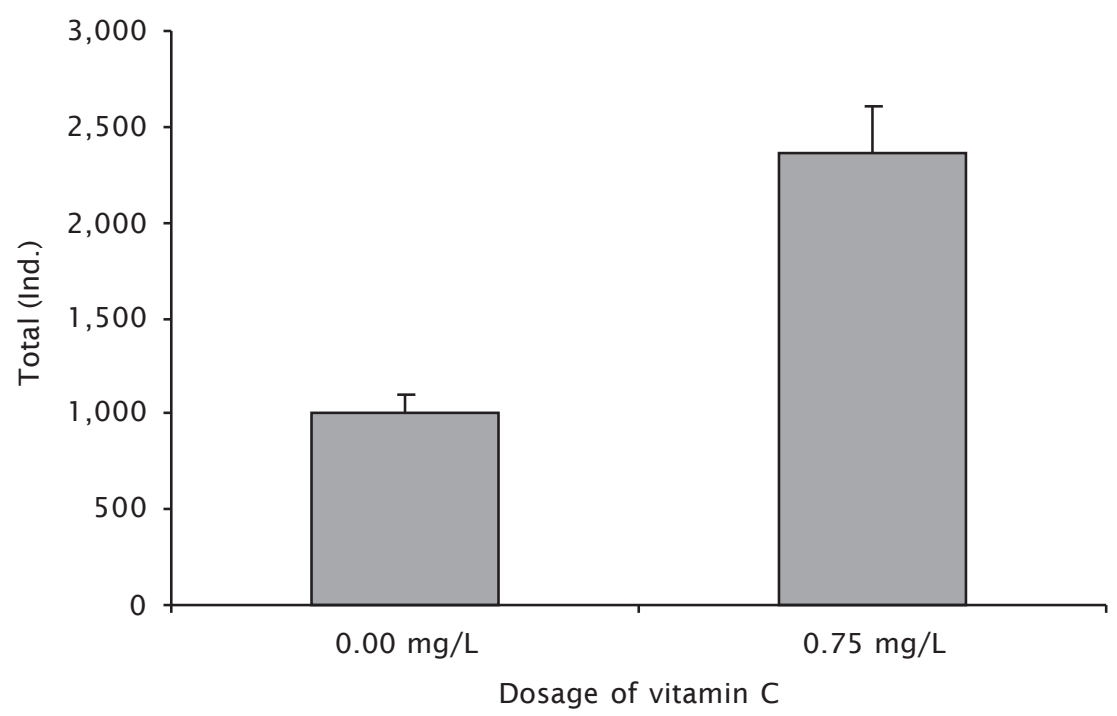

Figure 1. Total of freshwater prawn postlarvae on D25 in the trial

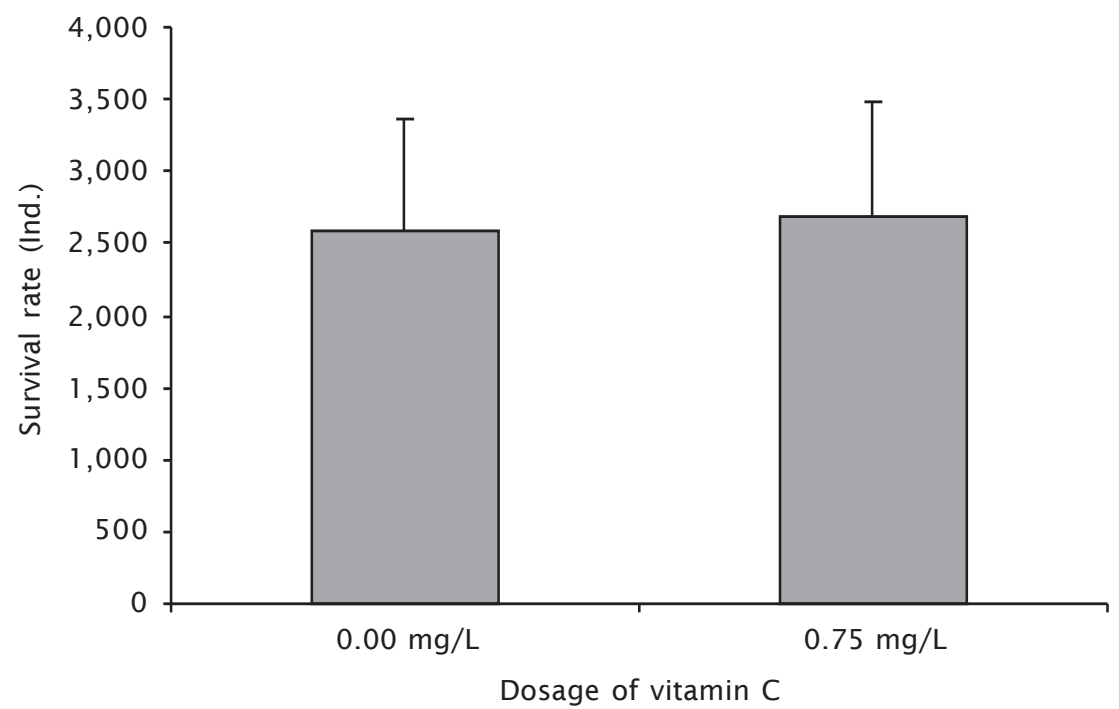

Figure 2. Survival rate of freshwater prawn larvae on D25

tion of survival rate at treatment of $0 \mathrm{mg} / \mathrm{L}$ will decrease because larvae stage more sensitive than pasca larvae from disease and environment stress.

\section{CONCLUSION}

To maintain high survival and growth rates of freshwater prawn larvae can be obtained by supplementing vitamin $\mathrm{C}$ into the culture media.

\section{REFERENCES}

Alava, V.R., A. Kanazawa, S. Teshima. 1993. Effect of dietary vitamins $A, E$, and C on the ovarian development of Penaeus japonicum. Nippon Susian Gakkaishi. 59 (7): 1235-1241.

Aquacop. 1983. Intensive larval rearing in Clear Water of Macrobrachium rosenbergii at Center Oceanologique Tahiti. Handbook of mariculture Biology. 1. Crustacean Aquacult. p.179-187. 
D’Abramo, L.R, M.W. Brunson and M.E. Fondren. 2002. Freshwater Prawns Hatchery and Nursery Management. Mississippi State University Press. Mississippi 10 pp.

Hadie, W., L.E. Hadie 1993. Pembenihan udang galah. Usaha Industri Usaha Industri Rumah tangga. PT. Kanisius. Yogyakarta. 110 pp.

Matsumoto, T., H. Hosokawa, and S. Shimeno. 1991. Ascorbic acid's role in aquaculture nutrition. In Proceedings of the Aquaculture Feed Processing and Nutrition Workshop. Edited by D. M. Akiyama and R.K.H. Tan. Thailand and Indonesia. September 19 25, 1991. American Soybean Associaion, Singapore.

Merchie, G., P. Lavens, H. Nelis, A.P. De Lenheer, P. Sorgeloos. 1993. Effect of vitamin C incorporation in live food on the larviculture success of aquaculture species. Med. Fac. Landbouww. Univ. Gent 58/4b: p. 1999-208.

New, M.B. 1995. Status of Freshwater Prawn farming: a review. Asean EEC Aquaculture Development and Coordination Pragramme, Bangkok, Thailand. 26: 1-54.

New, M.B. and W.C. Valenti. 2000. Freshwater Prawn culture. The farming of Macrobrachium rosenbergii farming. Blackwell Science, Oxford: 443 pp.

Spotte, S.H. 1970. Fish and Invertebrate Culture, Wiley Interscience. New York. 145 p.

Uno, Y. and K.C. Soo 1969. Larval Development of Macrobrachium rosenbergii (de Man) in The Laboratory. Journal of Tokyo University of Fisheries. 55(2):175. 